\title{
CURRENT PROBLEMS OF TEACHING PHILOSOPHICAL DISCIPLINES IN EDUCATIONAL INSTITUTIONS OF SLOVAK REPUBLIC
}

\author{
MARIÁN AMBROZY
}

\begin{abstract}
The paper is a brief mapping of the situation in the field of didactics of philosophy in the Slovak Republic. We observe that, despite almost three decades of separation of official philosophy from the dominance of Marxist philosophy, there is no satisfactory basis for the didactics of philosophy. The discipline Didactics of philosophy is represented by improvising several enthusiasts instead of developing serious theoretical foundations. We try to post a few recommendations that belong to all who want to seriously deal with the didactics of philosophy. The most important of them is the establishment of the Slovak scientific journal of didactics, the establishment of the organization of trade didactics, the separation of philosophy from other core subjects and the accreditation of the third level of university education in didactics of philosophy. The author convincingly proves the need to introduce knowledge of philosophy in school, since it will help teach students to think better, apply knowledge more effectively, critically evaluate everyday life, including relationships with parents, teachers, classmates and others. The article emphasizes that the experience of philosophizing will allow students to express their thoughts in writing, as well as to explore at an accessible level "eternal" issues of metaphysics, epistemology, natural philosophy, philosophy of history, philosophy of culture, philosophy of law, philosophical anthropology. philosophy of politics, etc. The urgency of impoving the teacher's competence in teaching this subject at school, in particular, updating the methodological support, substantiation of educational innovations for the use in the study of philosophy, as well as the introduction of ICT in the educational process are substantiated.
\end{abstract}

Keywords: professional didactics, teaching practice, philosophy at secondary school.

\section{INTRODUCTION}

Education, in addition to being one of the basic human rights, is a prerequisite for achieving sustainable development and an important tool for effective governance, informed decision-making and the development of democracy" [10, p. 26]. Although there are philosophical views that prefer the natural state, education can be generally considered necessary and important for human development [6, p. 141]. Didactics of philosophy is a discipline that is not given due attention in Slovakia. Currently, more than 10 people do not take care of this problem (optimistic estimate). Not only is there no numeric field code and in this form it is impossible to study it as a third degree of study (for example, as didactics of mathematics), but there is also no professional or scientific specialized journal dedicated to this field. There are not many of them in the world either. Among those which exsist we can mention the famous journal Teaching Philosophy. Two associate professors, two doctoral researchers, and a few 
keen high school professors, in one case working at a university, are willing to accept any publication in this field.

\section{THEORETICAL BASIS}

"Thinking about the competencies of a social science teacher means looking at him/her as a person who is one of the prerequisites for the success of learning in specific conditions and at a specific time" [5, p. 32]. Since the dominant share in the so-called topic of civic education in secondary schools, especially in gymnasiums, has philosophy, the competence of a philosophy teacher is in many ways important. They must be developed by didactics. In the post-war period, only 3 monographs were published in Slovakia, the topic of which was the didactics of philosophy. In 2002, Juraj Šch published a monograph "Selected Problems of Teaching Philosophy", in which 2003 comes out in the second revised edition. This act remained almost unique until 2013. This year, active researchers D. Durajkova and J. Šimkova published a monograph "Proposals for the implementation of philosophy in software according to a new concept". Despite the positive efforts of the authors to prepare materials on how to adapt the educational process to one year of philosophy, it should be said that for a year with a onehour scholarship, the teacher teaches no one and almost nothing, and the only way is to make a rose and transfer philosophy to a year where he/she has a two-hour scholarship. The author has practical experience in this area. The third book is a monograph by the author of the article Reflection of Philosophy in the Secondary School Curriculum, which attempts to reflect the interdisciplinary relationship of philosophy and other subjects.

Fortunately, there are positive developments as well. These undoubtedly include the work done so far in the field of didactics and methodology of philosophy by a high school professor dr. Štefan Bojnák, who taught at the gymnasium in Namestovo for many years. This enthusiast is the author of many valuable materials. First of all, it is necessary to mention the systematically oriented textbook "Civic Education for Secondary Schools II" - teacher's notebook and student's notebook. In addition to this quality study guide, he also produced a really excellent multimedia workbook and its use in philosophy lessons (2008). Dr. Bojnák can especially link the use of ICTs with teaching philosophy, his textbooks are of great importance, he has done a decent job, mainly as a methodology for teaching philosophy.

As a result of the project, a longer study entitled "Development of Reading Literacy in Philosophy Classes" was produced by active high school professor dr. Stebnicka [9]. Several articles were also prepared by a mgr. Gajdoš, who also collaborates with the University of Presov on the didactics of philosophy. Several articles were published by other authors (Vargova, Furjelova, Gondova, Bača, etc.). This is a relatively small number of outputs per 5 million states.

If we take the position on trade union didactics, we say that, with the exception of one case, it is read by people who have not published a monograph on the didactics of philosophy. Except for a few cases (Assoc.prof. Šuch, mgr. Gajdoš, etc.), they do not even have an ephemeral publishing activity within the framework of philosophy didactics. The rhetorical question of which of the teachers of philosophy didactics actively participated with reports on the didactics of philosophy in at least five countries of the world?

We perceive this situation as a consequence of some reasons: 1) as an unfortunate socialist remnant, there is still an inadequate connection between philosophy and the subject of the doctrine of society, respectively. citizenship, even in grammar schools. 2) increasing the number of hours in the school curriculum to such an extent that philosophy is taught in a particular gymnasium for 2 years is exceptional. 3) it is also very rare that philosophy didactics (not civics or society) is taught at the university by a person with significant years of experience in high school plus at least some relevant publications in this area - on philosophy didactics. In the Slovak Republic, we register with a high probability only one such case - mgr. Marek Gajdoš. 


\section{RESUlts AND Discussion}

Within this part of our research we attempt to provide some recommendations and mention the measures to be taken to improve the situation:

- Create an organization similar to the Czech Association of Teachers of Philosophy;

- Start a scientific journal on the didactics of philosophy;

- Develop and publish a monograph that will be a comprehensive introduction to the didactics of philosophy;

- Organize scientific conferences, the main topic of which is the didactics of philosophy;

- Develop a modern, lexically accessible to the student, but meaningful (and professionally correct) philosophy textbook (history oriented), even in an interactive version;

- Try to accredit the scientific area of philosophy didactics in postgraduate studies (similar to, for example, mathematics didactics);

- Separate the didactics of philosophy from the so-called "Didactics of civil sciences";

- Strive to support high school philosophy teachers who achieve the necessary conditions for academic work in this field;

- Pay more attention to establishing direct relationships between philosophy departments and grammar schools (including through the provision of part-time work);

- Introduce the principle at the faculties of philosophy, according to which didactics of philosophy should not be carried out by a person without the age of 7-10 years of internship in high school and without relevant publications and conferences;

- Maintain contacts with scienticts in the field of philosophy didactics in the world.

Let's describe the proposals in deeper detail. The Czech Association of Teachers of Philosophy operates in the Czech Republic. Slovakia does not have a similar establishment. Its creation will promote a synergistic effect in the form of cooperation between trade union didactics and other experts. For example, the members of the association could, in collaboration with historians of ancient philosophy, solve the problem of meaningfully explaining the problem of pre-Socratics to high school students in order to avoid peripatetic misinterpretations. With a collaborative, coordinated approach, such an association could do something meaningful.

An important task is to create a scientific journal on the didactics of philosophy. There is no such scientific journal in the Slovak, or even, it seems, in the Czech geographic space. There are several journals on this topic in the world, in addition to the mentioned Teaching Philosophy. There are also other journals devoted to the didactics of philosophy, which are published in various parts of the world, for example in Australia, France and Iran. The journal will open up space for the presentation of results at a scientific level. If the magazine moved abroad, it could be enriched with results outside Slovakia.

We consider it a key task to develop a basic monograph in Slovakia, which would become the main theoretical overview. In a situation where only three monographs are devoted to partial didactic topics, we consider this point extremely important. It is necessary to make a fundamental monograph, which would be a summary, a synthesis of the main topics, broken down by chapters. Its significance will lie in the theoretical training of practitioners (teachers), as well as in the systematization of basic knowledge for the needs of philosophy didactics in our country. Ultimately, the monograph under consideration will become the support of both theorists and practitioners.

It should be mentioned, in Slovakia there are no regular scientific conferences devoted to the didactics of philosophy. Although some of them were implemented, they were sporadic actions without any sequence. It is necessary to establish regular scientific events dedicated to the topic of teaching philosophy. This should be a meeting of all interested in the problem from the ranks of universities, research institutes and secondary schools, to which it would be appropriate to invite delegates from abroad. Interaction and the possibility of synergies that could potentially arise from possible discussion of specific issues will be the main goal of such events. Their frequency should be a guarantee of regular work within the framework of the topic. 
Perhaps the most important challenge is to develop a quality high school textbook that is historically oriented. Štefan Bojnák has already created systematically oriented workbooks that fill the blank space in teaching aids. Although several history-oriented secondary school philosophy textbooks have been developed in the Slovak edition, some of them were written in a very complex, overly dense style. Even after being explained, such textbooks were understood only by exceptionally gifted students. Some of them are written in a more acceptable form, but contain less information and in some cases are influenced by rather outdated interpretations. It is necessary to prepare a modern textbook that would be acceptable in terms of content and vocabulary for high school students (in our case, from 17 to 19 years old), but, on the other hand, it should not give little information or pay for old, already outdated interpretations. The best solution to the problem would be to prepare an interactive version of the textbook in question in parallel. An excellent step in this direction might be the subsequent publication of a teaching guide for teachers of philosophy.

The scientific community plays an important role in accrediting the scientific field of philosophy didactics as an official field in the same sense as mathematics didactics in Slovakia, for example. It can be studied as a third university degree. Such a step in the didactics of philosophy would not only affirm this discipline in the eyes of the wide scientific and professional community, but, in particular, would make it possible to create specialists in the didactics of philosophy. In addition to inseparable secondary schools, their workplaces will also have departments, scientific institutions and, of course, methodological centers.

Although colleagues from Nitra write: "The problem of didactics of the subject of civic consciousness is precisely the necessary reflection of constant changes in the content of the subject, reflecting its nature and direction, changes in didactic aspects and methodological processing" [8, p. 349]. I am writing honestly, but in this context it should be noted that the so-called didactics of the science of society (civics) is a vague concept, almost empty in content. There is only a partial didactics of the components of the social sciences, and the didactics of philosophy must be separated from specific components (law, economics, political science, sociology, psychology). The aforementioned authors admit: "The didactics of civic education is the focus of studying the orientation of teachers, and in the context of the general approach to university education in Slovakia, based on the relative autonomy of the approaches of individual schools, a unified approach in this area is impossible" [8, p.349]. If this is to be understood or taught as the so-called didactics of social science, the implementation of such university training is likely to harm its graduates in the form of very superficial didactic training.

There should be elementary collaboration between academic philosophy at universities and secondary school teachers [3]. Gifted and ambitious philosophy teachers should be motivated (by various forms of motivation) to their own professional and scientific work in the field of philosophy didactics (and not only in this area). It is necessary to bridge the still existing gap of great mutual isolation of philosophers working in universities and high schools. This gap can be bridged through preferential admission of third-level employees to secondary schools (subject to contacts with academic institutions), as well as through joint work at the university and secondary school, or in the academy of sciences. We must state that there are still a relatively small number of philosophy teachers in secondary schools with experience at the university, academy of sciences, as well as teachers of philosophy with relevant secondary school experience. This gap is the source of several problems. In this context, the principle should be introduced according to which a teacher of philosophy didactics must have relevant experience in secondary school, at least 7 years, and, of course, give the expected results.

Another important task is to ensure the connection of trade union didactics (not only) of philosophy in the world. "It is important that we educate the student in a subject that is not very easy for high school students, but now there are more and more new methods" [4, p. 24]. The Slovak didactics of philosophy should not lag behind world discoveries, procedures, be isolated [11]. Selected methodological procedures from other didactic disciplines, for example, the didactic discoveries of the 
famous Czech didactic mathematician Milan Hejny are largely applicable to the didactics of philosophy. Good philosophy didactics must ultimately be global.

\section{CONCLUSIONS}

The problem of philosophy didactics is also associated with the position of the humanities in the information society, which, according to Polačko (2019), has become problematic. Therefore, it is necessary to look for solutions to this situation.

Citizenship didactics is a vague and confusing concept. Although some theorists use it, there is really only a didactic of the various partial components of this artificial conglomerate of relatively few interrelated subjects. In this context, we note his deep disregard. Hiding behind general phrases copied from the state educational program, but with innovations in the framework of various professional and scientific articles on the so-called didactics of citizenship, it cannot be regarded as an indirect development of professional didactics of philosophy. In this article, we have highlighted several necessary components to address the near-critical state of philosophy didactics in Slovakia. Perhaps they will be resolved in the coming years.

The article was prepared within the framework of the IG-KSV-01/2020-12-33/IP grant project.

\section{REFERENCES}

[1] Ambrozy M. Práca s textom vo vyučovaní filozofie. In: Sociálne posolstvo Jána Pavla II. pre dnešný svet: 198925 rokov po... Ružomberok, Verbum, 2015. (in Slovak)

[2] Ambrozy M. Význam tvorivého písania v didaktike filozofie. In: Nová sociálna edukácia človeka IV: Duchovné, antropologické, filozofické,psychologické a sociálne aspekty terapie, výchovy,vzdelávania a poradenstva dneška. Prešovská univerzita v Prešove, Prešov, 2016. (in Slovak)

[3] Furjelová A. Ked’ sa povie didaktika filozofie. In: Philosophica 33: filozofia v škole, filozofia v živote. Univerzita Komenského, Bratislava, 2002. (in Slovak)

[4] Gondová A. Material Resources on Philosophy Lessons. In: Quality of Life, Social and Ethical Dimensions IX (2018), 21-24.

[5] Jonášková G., Lomnický I., Predanoczyová L. Didaktiky spoločenskovedných predmetov občianska náuka a etická výchova. UKF, Nitra, 2018. (in Slovak)

[6] Polačko J. Niekolkko poznámok k úlohám humanitných vied v informačnej spoločnosti. In: Vysokoškolské vzdelávanie v modernej spoločnosti. Technická univerzita v Košiciach, Košice, 2019. (in Slovak)

[7] Polačko J. Kríza Covid-19 ako príležitosṫ. Zmena myslenia a adaptácia vzdelávania. In: Vzdelávaním k perspektívnemu uplatneniu (motivácia, kompetencie, adaptácia, pracovný trh). Technická univerzita v Košiciach, Košice, 2020. (in Slovak)

[8] Predanoczyová L., Jonášková G. Aktuálne problémy didaktiky občianskej náuky. In: Inovatívne trendy v odborových didaktikách. Nitra, UKF, 2019. (in Slovak)

[9] Stebnická A. Rozvíjanie čitatel’skej gramotnosti na hodinách filozofie. Príprava žiaka na ÚFIČ MS. Metodicko - pedagogické centrum, Prešov, 2012. (in Slovak)

[10] Šeben Zaťková T., Marinicová P. Ekologická a enviromentálna výchova ako súčast̉ $\mathrm{k}$ udržatelnému rozvoju. Slavonic Pedagogical Studies Journal, 7 (1) (2018), 22 - 40. (in Slovak)

[11] Šuch J. Vybrané problémy z vyučovania filozofie. Metodicko-pedagogické centrum, Prešov, 2002. (in Slovak) 
Address: Marián Ambrozy, College of International Business ISM Slovakia in Prešov, Duchnovicovo námestie 1, Prešov 080 01, Slovakia.

E-mail: ambrozy.marian@gmail.com.

Received: 12.02.2021; revised: 25.03.2021.

Амброзі Маріан. Актуальні проблеми викладання філософських дисциплін в освітніх закладах Словацької Республіки. Журнал Прикарпатського університету імені Василя Стефаника, 8 (1) (2021), 116 121.

Пропоноване дослідження являе собою коротке відображення ситуації у галузі дидактики філософії Словацької Республіки. Автором висвітлено думку про те, що, незважаючи на майже три десятиліття відокремлення офіційної філософії від домінування марксистської філософії, не існуе задовільної бази для дидактики філософії. Науково-методичний супровід дисципліни, проаналізованої у дослідженні, представлений напрацюваннями кількох дослідників-ентузіастів, замість розробки серйозних теоретичних основ. У статті представлено кілька рекомендацій, які належать тим науковцям, які хочуть змінити підхід до навчання дидактики філософії. Найважливішим 3 них є створення словацького наукового журналу дидактики, налагодження організації торгової дидактики, відокремлення філософії від інших основних предметів та акредитація третього рівня університетської освіти з дидактики філософії. Автор перекондиво доводить потребу впровадження знань з філософії у школі, адже це допоможе навчити учнів краще мислити й розмірковувати, ефективніше застосовувати свої знання, критично оцінювати повсякденне життя, зокрема взаємини з батьками, вчителями, однокласниками та ін. У статті акцентовано на тому, що досвід філософствування дасть змогу учням письмово висловлювати свої думки, а також на доступному рівні досліджувати “вічні" питання метафізики, гносеології, епістемології, натурфілософії, філософії історії, філософії культури, філософії права, філософської антропології, соціальної філософії та філософії політики тощо. Доведено актуальність підвищення компетентності вчителя щодо викладання цього предмету в школі, зокрема оновлення методичного забезпечення, обгрунтування освітніх інновацій для використання при вивченні філософії, а також упровадження ІКТ в освітній процес.

Ключові слова: професійна дидактика, викладацька практика, філософія у загальноосвітній школі. 